\title{
Sex workers' narratives about clients with disabilities: can training improve sexual health in Portugal?
}

\section{Narrativas de trabalhadores(as) do sexo sobre clientes com diversidade funcional: poderá a formação melhorar a saúde sexual em Portugal?}

\author{
Ana R. Pinho a \\ (D) https://orcid.org/0000-0002-9190-8094 \\ E-mail: psic.anapinho®gmail.com \\ João Manuel de Oliveira ${ }^{b, c}$ \\ (D) https://orcid.org/0000-0002-2793-2946 \\ E-mail: joao.m.oliveiraœgmail.com

\section{Conceição Nogueira ${ }^{a}$} \\ (iD) https://orcid.org/0000-0002-9152-754X \\ E-mail: cnogueira®fpce.up.pt \\ aUniversidade do Porto. Faculdade de Psicologia e Ciências da \\ Educação. Centro de Psicologia. Porto, Portugal. \\ 'Instituto Universitário de Lisboa. Centro de Investigação e de \\ Intervenção Social. Lisboa, Portugal. \\ 'Universidade Federal de Santa Catarina. Programa de \\ Pós-Graduação em Psicologia. Florianópolis, SC, Brasil.
}

\section{Abstract}

People with disabilities face barriers that limit their sexual lives. In Portugal, some individuals with physical impairments have shown interest in resorting to sexual assistance provided by trained professionals, according to the client's preferences and needs. However, in Portugal, sex workers lacking any formal training represent the only way to access commercial sex services. Thus, this study analyzes the experiences of sex workers that provide services for disabled clients. The interviews of thirteen sex workers were analyzed using the thematic analysis method proposed by Braun and Clarke. The key findings show that men seek out sexual and emotional satisfaction from sex work. Additionally, specificities inherent to the lack of training and the relationships established tend to embarrass professionals. Finally, we conclude that training coupled with sexual education and popular awareness about gender differences in the pursuit of sex is fundamental to improve the sexual health of those who choose sex services as a way of sexual expression.

Keywords: Sexuality; Disability; Sex Work; Sexual Assistance; Sexual Health; Portugal.

\section{Correspondence}




\section{Resumo}

As pessoas com diversidade funcional enfrentam barreiras que limitam suas vidas sexuais. Em Portugal, alguns indivíduos com incapacidades físicas demonstraram interesse em recorrer à assistência sexual, prestada por profissionais com formação, para responder às suas preferências e necessidades sexuais. Contudo, trabalhadores(as) do sexo, sem formação específica, representam a única forma de aceder a serviços sexuais comerciais. Assim, este estudo foca as experiências de trabalhadores(as) do sexo que prestam serviços a clientes com diversidade funcional. Treze entrevistas a trabalhadores(as) do sexo foram analisadas pelo método proposto por Braun e Clarke. Os principais resultados demonstraram que os clientes do trabalho sexual são majoritariamente homens e que as especificidades inerentes tanto à falta de formação como às relações estabelecidas tendem a gerar sentimentos de constrangimento nos(as) profissionais. Finalmente, concluiu-se que a formação aliada à educação sexual e uma reflexão crítica sobre as diferenças de gênero existentes no recurso ao sexo comercial são fundamentais para melhorar a saúde sexual daqueles(as) que escolhem os serviços sexuais como forma de expressão sexual.

Palavras-chave: Sexualidade; Diversidade Funcional; Trabalho Sexual; Assistência Sexual; Saúde Sexual; Portugal.

\section{Introduction}

\section{Sexual health, sexual rights and disability}

Sexuality, from a psychological perspective, is an integral part of human life (WHO, 2015), and the way of living it can impact a persons' health (Gammino; Faccio; Cipolletta, 2016; Girard; Sastre; Mullet, 2018). Therefore, sexual health as a state of physical, mental and social well-being should be accessible for everyone and contemplate a "positive and respectful approach to sexuality and sexual relationships, as well as the possibility of having pleasurable and safe sexual experiences, free of coercion, discrimination and violence" (WHO, 2015, p. 5).

The Convention on the Rights of Persons with Disabilities declared equal access to health services and programs, including those in the field of sexual and reproductive health, as an international human right (UN, 2007). Recently, the declaration on sexual pleasure reinforced the right to equality while pursuing sexual pleasure (WAS, 2019). However, some groups continue to have their sexual rights denied. That is the case of people with disabilities, who face multiple barriers and stereotypes (Fritsch et al., 2016).

Disability is a complex concept with different interpretations. Nevertheless, at this point, a definition is needed to contextualize how the sexuality of people with disabilities has been approached. To establish a common ground, we resort to the World Health Organization, which refers to disability as a term that encompasses impairments, limitations and participation restrictions (OMS, 2004).

People with disabilities might feel vulnerable when it comes to their sexuality, since society defines standards that exclude everyone who do not fit into them (Mannino; Giunta; Fiura, 2017). Thus, isolation is still common among this population due to the lack of opportunities to access their surrounding community, leading to limited contacts with others, poor social skills and, consequently, fewer intimate relationships (Lane; Cambridge; Murphy, 2019; Limoncin et al., 2014). In addition, the concept of attractiveness encapsulates a perfect body image that devalues non-normative bodies (Bahner, 2015; 
Jones, 2012) and perceives them as less attractive (Cardoso, 2006), reinforcing this vicious circle of loneliness. People with disabilities are often seen as asexual (Lane; Cambridge; Murphy, 2019; Loja, 2014; Santos; Santos, 2017) and, for this reason, their sexuality has been repressed over the years (Liddiard, 2014). Specifically in Portugal, Santos \& Santos (2017) draw attention to a constant desexualization of this group of people. Moreover, recent research on the perspectives of Portuguese people with physical impairments about their sexual health point out to several physical, social and economic barriers, such as lack of accessibility in public spaces, social isolation, stereotypes, and poor financial support (Pereira; Teixeira; Nobre, 2018).

Some people with disabilities show a desire for romantic relationships as the base of sexual expression (Gammino; Faccio; Cipolletta, 2016; Lane; Cambridge; Murphy, 2019). In fact, the sexual sphere is more easily addressed by health professionals when the person is in a relationship (Pereira; Teixeira; Nobre, 2018); in a dating scenario, general population also manifest higher acceptance towards the sexuality of people with disabilities (Girard; Sastre; Mullet, 2018). Yet, nondisabled people, fearing social stigma and possible dependency, report concerns in establishing a relationship with people with disabilities (Hunt et al., 2017). Most people with disabilities perceive themselves as sexual beings but they cannot help feeling excluded by people without disabilities, who keep questioning their ability to sexually express themselves (Rohleder et al., 2018). Additionally, they notice a restriction of sexuality to penetrative practices, such as sexual intercourse, which neglects other sexual practices that lead to intimacy and sexual pleasure as well (Rohleder et al., 2018; Santos; Santos, 2017). Despite the barriers, the group of people with disabilities is diverse and include individuals who do have satisfying sexual lives, while most still complain about the difficulty of achieving sexual fulfillment (Gammino; Faccio; Cipolletta, 2016).
Several studies addressing commercial se ${ }^{1}$ show the existence of clients with disabilities (Freckelton, 2013; Fritsch et al., 2016; Gammino; Faccio; Cipolletta, 2016; Lane; Cambridge; Murphy, 2019; Sanders, 2006, 2007; Wotton, 2016), which can be an alternative adopted by them to overcome obstacles and stereotypes concerning their sexual expression. This search might stem from one or more of the following reasons: (1) dissatisfaction with their sexual lives and search for sexual gratification (Poelzl, 200o); (2) social or psychological deficits (Poelzl, 2000; Sanders, 2006); (3) loneliness, difficulty in establishing an intimate relationship due to physical and socio-cultural barriers, such as accessing public spaces, non-normative bodies, control over their autonomy by family members, and fear of sexual or social inexperience (Jones, 2012; Liddiard, 2014; Poelzl, 200o; Sanders, 2007); (4) selfperception of being unattractive (Poelzl, 200o); (5) necessity of feeling a sexual touch (Liddiard, 2014); (6) desire to experience different sexual practices and improve their sexual skills for future relationships or for sharing in a social context (Liddiard, 2014; Poelzl, 2000); (7) curiosity about this type of experience (Sanders, 2007); (8) maintenance of the body's sexual functions; (9) knowledge about their bodies and sexuality (Liddiard, 2014); and finally (10) the convenience of getting involved in sexual practices that neither require games of seduction nor reciprocity in gratification (Jones, 2012; Liddiard, 2014; Sanders, 2007). Thus, the interest or even the search for commercial sex services does not simply represent a matter of satisfying a sexual impulse, but rather of seeking quality of life (Browne; Russell, 2005), which reflects the issue of sexual health as a human right.

\section{Commercial sex services for people with disabilities}

There are different ways and means of providing sexual services or assisting people with disabilities to achieve sexual expression (Wotton, 2016). One of them is sexual assistance, a service based on a

\footnotetext{
Commercial sex is defined by Sanders (2007) as payment for any service that promotes the sexual expression of a person and constitutes one of the several forms of sexual facilitation. There are other types of sexual facilitation that do not involve commercial liaisons even while this study focuses on this concept, which covers sex work and sexual assistance when financial questions are involved.
} 
sex- positive discourse that defends each person's sexuality as unique and contemplates multiple experiences and preferences (Williams et al., 2015). Sexual assistance is provided by professionals who are trained in efficient communication, relaxation techniques, sexual touch (Limoncin et al., 2014; Poelzl, 2000; Shapiro, 2002), and in the practical issues of sexual education in order to enhance the sexuality of people with disabilities (Gammino; Faccio; Cipolletta, 2016). The activities they engage in involve either non-penetrative practices (massages, masturbation, sex toys and discussions about sexual aspects or contraception) or penetrative practices (intercourse and oral sex). However, two main controversial issues are highlighted. On the one hand, the similarities between sexual assistance and sex work (Geymonat, 2019). On the other hand, the risk of clients' emotional involvement (Lambelet, 2017; Mannino; Giunta; Fiura, 2017).

According to Gammino, Faccio and Cipolletta (2016), some sex workers lack the sensitivity necessary to satisfy the needs of clients with disabilities. Untrained professionals such as sex workers are more often motivated exclusively by the monetary aspect, engage more in penetrative practices and can be involved in situations of violence, stigmatization and power abuse (Gammino; Faccio; Cipolletta, 2016; Geymonat, 2019; Lambelet, 2017; Limoncin et al., 2014), as opposed to trained professionals, who favor nonpenetrative practices (Chrastina; Vecerová, 2020; Lambelet, 2017; Limoncin et al., 2014; Shapiro, 2002). Their work, beyond sexual satisfaction, focuses on developing the self-esteem of their clients who begin to experience sexuality and start perceiving their bodies as attractive and meaningful (Shapiro, 2002). Moreover, sexual assistants are trained to clarify possible romantic feelings (Geymonat, 2019) and can address the positive aspects of consensual penetrative practices (Shapiro, 2002), reducing possible vulnerabilities (Gammino; Faccio; Cipolletta, 2016).
Multiple associations available in the European Platform Sexual Assistance (EPSEAS), which represents partners in different European countries, play an important role in connecting sexual assistants with disabled clients and ensuring their safety, as well as responsible practices guided by knowledge and ethical principles (Freckelton, 2013; Jones, 2012).

Regarding legal issues, countries tend to apply the same legal status of sex work to sexual assistance, considering both as commercial sex services because there is financial transaction involved (Freckelton, 2013). Different authors refer to sexual assistance already holding a proper legal status in Germany, Switzerland and the Netherlands (Chrastina; Vecerová, 2018; Gammino; Faccio; Cipolletta, 2016; Geymonat, 2019; Limoncin et al., 2014), the latter being a state that assures sexual assistance to some people with disabilities (Fritsch et al., 2016; Sanders, 2007). Even without legal recognition, there are people performing sexual assistance in other countries (e.g. Denmark and Spain) (Mannino; Giunta; Fiura, 2017). In Portugal, legal framework for sex commercial services does not exist ${ }^{2}$, but some of the 26 Portuguese participants on the study of Pereira, Teixeira and Nobre (2018) suggested the creation of sexual assistance to facilitate sexual practices and pleasure, because they were interested in learning sexual techniques from these professionals.

\section{Study Aims}

Pereira, Teixeira and Nobre (2018) found people interested in benefitting from sexual assistance, but in Portugal there is no incidence of this type of service, and the issue was not brought up in the scientific literature. The absence of references on commercial sex for clients living with disabilities were also observed. Thus, we approached sex workers who acknowledge having an active role in the provision of sex services and knowing the only

2 The only reference in the Portuguese criminal code directly related to commercial sex services is pandering (Oliveira, 2017). Thus, as mentioned in law no. 59/2007 of September 4, article 169 no. 1 "Whoever, professionally or with profitable intention, incites favors or facilitates another person's engagement in prostitution is punished with a sentence of imprisonment from six months to five years" (Portugal, 2007, p. 6190). 
way to access commercial sex in Portugal. With this study we aim to observe the experiences of sex workers with clients with disabilities, analyzing how training could impact it.

Our study is the first to emphasize this phenomenon in the Portuguese context, and we hope to contribute to debunking stereotypes alongside addressing practical measures to improve the quality of life of both sex workers and people with disabilities.

\section{Method}

\section{Participants}

The target population of this research were people with experience as sex workers.

To recruit the participants, we applied a convenience sampling method. Psychologists who had close professional relationships with the target population divulged the study aims and, subsequently, people who showed interest in collaborating were contacted by phone. The locations where the meetings took place were selected by the participants, to ensure a safe and comfortable environment to talk openly about this topic.

We carried out thirteen interviews after the signing of informed consent forms.

All participants had experience as sex workers ranging from 6 months to 39 years, with eleven still actively exchanging sex services for money at the time of the study. Their ages ranged from 20 to 58; six people identified themselves as females $(\mathrm{F})$, of which three were trans women (MF), and seven as males (M). Most individuals were Portuguese $(n=9)$, only four were Brazilian. As for their sexual orientations, six people identified themselves as heterosexual, five as homosexual and two as bisexual. In terms of education, two participants had undergraduate degrees, three had secondary education and three attended primary education. The other five participants left school before completing any formal qualification. Ten of the thirteen participants indicated religious beliefs. Finally, only five individuals reported having friends or family members with disabilities.
We asked sociodemographic questions at the end to avoid feelings of hesitation over answering personal questions when a closer relationship was not yet established.

The sample collection ended when the theoretical saturation point was reached, which means that the interviewers were no longer adding information relevant to answering the research questions (Fontanella et al., 2011).

\section{Data collection}

It would be naive to believe in the existence of any single or unique reality. There are several different versions of reality, depending on the respective context, and people tend to express personal interpretations of their experiences (Braun; Clarke, 2013). In order to deepen the access gained to someone's world, we adopted a qualitative paradigm.

This is an exploratory study as there is no scientific literature on the search for commercial sex for clients with disabilities in Portugal. Hence, we used semi-structured interviews to collect the data to increase flexible and spontaneous answers about a sensitive topic (Boni; Quaresma, 2005). After introduction, the interview guide explored sex workers' experiences with disabled clients, their perceptions of people with disabilities and measures to improve sex services. Participants spoke freely about their opinions and professional experiences, relating them to other themes they considered important. To gather the rich content of the narratives and promote a closer interaction (Alves; Silva, 1992), all this information was recorded in audio format. Written informed consent forms were obtained from all participants included in the study.

The average duration of these face-to-face interviews was 31 minutes, with a minimum of 15 minutes and a maximum of 62 minutes.

\section{Data analysis}

Participants' narratives result from a social construction shaped and influenced by their historical and sociocultural backgrounds. Therefore, in order to understand the subjectivities presented in 
these discourses, we performed a thematic analysis. This analytical tool gives a detailed description of the qualitative data by identifying the underlying interview patterns (Braun; Clarke, 2006).

The phases of thematic data analysis followed the proposals made by Braun and Clarke (2006, 2013). Initially, we transcribed the interviews verbatim into Word documents and performed a preliminary analysis after each interview to use the information obtained and verify the saturation criteria. Subsequently, the analysis began, and the information was read as well as processed several times before taking the first notes. Then we proceeded with the codification of the segments relevant to the study before the third step grouped these codes into possible themes with broader meanings. After reviewing the themes and their relation to the illustrative segments presented in the texts, we drafted a thematic analytical map as a result of the fourth phase. The fifth phase focused on clarifying the singularity of each theme before writing the findings alongside illustrative extracts of the narratives in the final step.

\section{Results}

The sex workers' narratives revolve around a central organizing concept, that is "experiences with disabilities," which reflect how the four themes of the thematic analysis result in the interactions between sex workers and the disabled people who sought for sexual services.

\section{Search for sex work}

All thirteen participants interviewed recalled at least one experience with a client with some type of disability. However, when asked about the frequency of such contacts the opinions diverged. For some respondents, there is a high demand, which justifies the need to improve the conditions of the service provided. For others, such investments hold little value: there is so little demand within this group that it is just not worth it (P1.M, November 29, 2016). However, this latter perception might be inaccurate since five of the thirteen participants stated that clients with disabilities always seek out sex professionals. They always do. They don't come to me every time... not every week or every month, but they always search for that pleasurable moment (P10.M, March 7, 2017).

The participants mentioned that people with disabilities tend to search for commercial sex autonomously. Only four sex workers referred to situations in which the initial contact and transport was made by an intermediate. In three cases, sex professionals accessed directly the client's house, because he was in a wheelchair and asked me to visit him due to the lack of elevator in my building (P6.M, December 22, 2016).

Phone calls are the most common way to get in touch with sex workers, although four participants reported situations in which the client with disability approached them on the street, by using an adapted car or by foot.

The interviewees described clients with disabilities as a heterogeneous group. They spanned different ages, sexual orientations, socioeconomic backgrounds and lived in distinct parts of the country. The types of disabilities also differed. Twelve participants talked about clients with physical impairments and six referred to people with mental, visual or hearing disabilities. The only common aspect present in all the discourses was the fact that they were all male.

\section{Sex workers' motivations and experiences}

Several were the explanations given to why sex workers attend clients with disabilities. All participants mentioned economic motivations as the main reason. For five, this was the only motive and a matter of survival, while, for the other eight, it was an option to obtain the yields desired. Among the sex workers who provide services to obtain a desired level of income, four specify other types of motivation that fell beyond any exclusive focus on their financial benefits. The reasons referred to were the following: companionship as

Sometimes a client arrives when we are alone, and it's companionship, you know? I do the work, we talk, then he sits there in the living room [...]. Occasionally, I even turn the music on, "Let's dance love, let's do some exercises," and they laugh. (P12.F, March 13, 2017) 
Self-knowledge and pleasure as illustrated below:

I started this work not only for economic reasons but also out of curiosity [...], trying to understand how a blind person would give me pleasure and how they would experience it with me. It was very interesting. I felt like I could perceive it, and with a physically disabled person too [...], they seek pleasure, perhaps, in the care you provide to them, in the contact you have with them, in the visual observation. (P2.M, December 2, 2016)

And social motives because, as one of the sex workers informed us, this work:

avoids breaking up marriages, avoids rape and avoids a lot of other things. In France, they decided to put an end to sex work [...], which increased sex crimes, incest, especially family members taking advantage of people with Down syndrome, physically disabled people, and older people just to have sex. So, sex work is a kind of social work that deserves all the respect in the world. (P13.MF, March 15, 2017)

Moreover, sex workers portrayed both positive and negative experiences that influenced the way they view and interact with this group of clients. The reporting of more negative experiences was observed in the narratives of sex workers attending clients with disabilities, exclusively because they needed the money to survive. This reflects the case of a woman who told us about her experiences with clients with hearing disabilities:

A few years ago, I used to go with deaf-mutes but now I don't, because they are mean, they are very rude. They grab a person too tightly, they are crazy, they tighten. I even fear they will stifle me. [...] we can't breathe, and we speak but they don't hear. (P5.F, December 21, 2016)

Other discourses showed positive experiences such as the following:

I have a regular client with a hearing disability in the south [...] he doesn't hear, and we can't understand what he says but it is funny because we use the mobile phone to communicate. [...] He is an excellent person. He is a young boy, and he is very sweet, very affectionate. (P6.M, December 22, 2016)

\section{Services provided to clients with disabilities}

The sexual services provided to disabled clients were based on penetrative and non-penetrative practices. Twelve of the thirteen participants engaged in penetrative practices (oral, anal or vaginal sex) but, in several circumstances, the preference was for affection, communication and touch because the person has a tactile sensation and just by touching their skin they have a much more perfect orgasm than with the sex act itself (P2.M, December 2, 2016). Therefore, massages, performances (i.e. stripping) and companionship were frequent requests made by clients with disabilities. Sex workers perceived a desire for proximity and emotional fulfillment, as well as sexual gratification, especially when these clients insisted on giving them massages or extra amounts of money as gifts. In the words of one participant, clients

also look for companionship because they don't have it in their daily lives. Of course they look for sex because they want it too, but they mostly seek someone to talk to and go out as if it was a personal relationship. ( $\mathrm{P} 7 . \mathrm{M}$, January 12, 2017)

Participants described the practices involving touch as more demanding and time consuming. Therefore, two sex workers told how they increased the prices charged to this group of clients, while another two said they have considered doing the same, I recognize that if it's a person with severe limitations that needs more time [...] in that case, the price charged must be different (Pg.F, March 6, 2017). Some denied asking clients with disabilities for more money but to be honest I've got friends who do so. They charge more because they don't feel good attending these clients ( $\mathrm{P}_{5} . \mathrm{F}$, December 21, 2016).

\section{Obstacles and possible solutions to access commercial sex}

Fears of fragility, emotional dependence, compassion and exhaustion were mentioned when 
talking about interactions between clients and sex workers. Furthermore, ten participants reported feelings of embarrassment while providing services to clients with disabilities. The non-normative body and differences in clients' behaviors were the reasons attributed to these uncomfortable feelings, which in some exceptional cases led sex workers to refuse providing the sexual service to the client.

Regardless of such feelings, professionals agree that commercial sex should be accessible to everyone because they notice the strong will of people with disabilities to express their sexuality; they suggest these services might be a solution in some cases as it's harder for them to move. So, if they come it is because they really want to be with someone (P11.MF, March 13, 2017). However, there still remain numerous obstacles, such as physical barriers, autonomy restrictions, lack of economic resources, trouble in getting sexually aroused to perform sexual services, communication barriers, and sex workers who do not consider that the provision of a satisfactory service requires patience, sensitivity, communicative skills and serviceability. Therefore, training was commonly referred to improve the current situation. Most sex workers interviewed did not have the knowledge of sexual assistance but perceived training as an important solution to understand how to adopt a professional attitude and provide a good service to people with disabilities. One of the participants said: I think it's crucial, because otherwise it can be a traumatic experience. If a person goes to a professional who is not prepared and trained to attend the client with disabilities, the cure could be worse than the disease (P13.MF, March 15, 2017). They also mentioned the importance of investing in training for people with disabilities and their families, so they can make conscious decisions. Training was seen as a measure to ensure safety and health. Other forms of facilitating equitable access to sex work were: (1) legalization of sex work; (2) the existence of intermediaries able to transport people with lower autonomy levels to sites of commercial sex services; (3) the creation of a space with hygienic and safe conditions for sexual services provision; (4) conferences by sex professionals promoting reflections about their practice; (5) demands for sexual rights; and, finally, (6) provision of financial support and funding by the government.

\section{Discussion}

This study aimed to observe if there are Portuguese clients of commercial sex living with disabilities and to explore sex workers' experiences with this group. Our finding coincides with several results obtained in international research (Freckelton, 2013; Geymonat, 2019; Sanders, 2006, 2007), reinforcing that sex workers also provide sex services to people with disabilities in Portugal. However, the perceptions of sex professionals about the demand for sex work vary, as opposed to the data obtained in the survey of the United Kingdom carried out by Sanders (2007), who reported a higher percentage of people with disabilities using sexual services compared with people without disabilities. This might be explained when people with disabilities mention the lack of resources and social stigma in the Portuguese context, which directly affects sexuality and leads to sexual inhibition. Even the clients who overcome the difficulties of accessing sex work tend to search for commercial sex services by themselves because social networks do not help them achieve sexual expression (Pereira; Teixeira; Nobre, 2018).

Although there is already a report of women using sexual assistance services in Europe (Geymonat, 2019), Portuguese clients with disabilities approaching commercial sex as a means of expressing their sexuality are often men with a physical impairment, similar to most of the clients reported by other international research (Bahner, 2015; Jones, 2012; Liddiard, 2014; Sanders, 2007). This finding highlights the presence of gender differences, also mentioned in the study of Liddiard (2014), in which several women answered with laughter or shock, followed by silence, when asked about considering commercial sex services. Furthermore, in Gammino, Faccio and Cipolletta (2016), women's sexuality was described as less strong than men's. The gap in the literature concerning payment for sexual services by women (Liddiard, 2014; Sanders, 2007) may be attributed to the conflict between women's sexuality and the norms imposed in the heteronormative sexual culture (Liddiard, 2014). Sex is still linked to a reproductive function (Lambelet, 2017), and women 
tend to lose the social role of motherhood when they live with disabilities (Gesser; Nuernberg; Toneli, 2012), resulting in the desexualization of this group (Santos; Santos, 2017).

As to sex professionals, they all expressed an economic motivation. In some cases, an altruistic posture emerged such as companionship, selfknowledge, pleasure and social motives, while also generating a significant impact on clients' lives. The literature associates these types of motivation with trained professionals, but, as we observed in participants' sociodemographic characteristics and as reported, sex workers are an heterogenous group of people, which can sometimes result in shared dimensions between both trained and untrained professionals. Nonetheless, the most of them attend clients with disabilities exclusively for money (Limoncin et al., 2014). The results also emphasize how sex workers perceive patience, sensitivity, good communicative skills and serviceability as essential even if these qualities are not present in every professional. According to the discourses in the study of Gammino, Faccio and Cipolletta (2016), only people with a 'natural aptitude' for providing services to clients with disabilities should be selected and trained. Indeed, we observed here how personal characteristics, motivations and experiences of sex workers influence the way these interactions get established and the services provided. Their narratives allow us to conclude that positive experiences, personal traits and motivations beyond the financial returns generate a good impact on people with disabilities.

The discourse of sex workers match the interest expressed by Portuguese people with disabilities in experiencing sexuality and pleasure (Pereira; Teixeira; Nobre, 2018), which is a human right (WAS, 2019). The involvement of penetrative practices was frequent and are common among untrained professionals (Limoncin et al., 2014). Intercourse is not necessarily negative because the scope for experiencing sexuality through sexual gratification enables clients with disabilities to boost their self-esteem by refuting their image as asexual beings imposed by society (Shapiro, 2002). However, the narratives in this study showed how alternative forms of expressing sexuality were also requested by clients with disabilities. Cardoso (2006) explains this might stem from an increase in appreciation for the affective sphere and the desire for romantic relationships (Gammino; Faccio; Cipolletta, 2016; Lane; Cambridge; Murphy, 2019). Romantic, stable and monogamous relationships (Limoncin et al., 2014; Gammino; Faccio; Cipolletta, 2016) are the ones recognized and socially accepted (Girard; Sastre; Mullet, 2018), which might influence what people request in sex services. Here, we observe that touch, dialogue, and non-penetrative practices, essentially performed by sexual assistants (Freckelton, 2013), are also services provided by sex workers. The professionals interviewed tend to perceive these preferences as a desire for emotional attachment, instead of a different way of achieving pleasure (Santos; Santos, 2017), and they fear the illusion that clients might create when the initial feelings of being loved and desired lead to fantasies that acquire a genuine dimension for them and end up in feelings of rejection, as if they had been used by sex workers, which "is inevitable in the context of a relationship that is not based on authentic, reciprocated affection or attachment but is in essence a transaction constituted by provision of negotiated services, albeit intimate, for a fee" (Freckelton, 2013, p. 644-645). Geymonat (2019) consider that the training of sexual assistants provides skills to address and clarify these situations, while alerting for the fact that all involved are adults, and they have the ability to protect themselves.

The lack of understanding possible delays in the services provided and knowledge of how to deal with non-normative bodies or with non-penetrative practices results in experiences accompanied by feelings of embarrassment (Sanders, 2007), explicit in almost every narrative. To avoid uncomfortable feelings of working with clients with disabilities, some sex workers responded with rejection, similar to that observed by Gammino, Faccio, Cipolletta (2016). Thus, training and raising awareness about equitable treatment would provide more appropriate approaches, since it would allow professionals to gain more confidence to deal with diversity.

The public space projected for normative people hinders the way people with disabilities 
move (Gammino; Faccio; Cipolletta, 2016), with restrictions imposed by institutions or family members limiting their autonomy (Gammino; Faccio; Cipolletta, 2016; Jones, 2012; Liddiard, 2014), the scarcity of job opportunities is another obstacle to ensuring their own income (Loja, 2014). Their self-perception as less attractive because of the difficulties in achieving the sexual arousal of sex workers (Bahner, 2015; Cardoso, 2006; Jones, 2012) and the lack of social/emotional skills of some sex workers (Gammino; Faccio; Cipolletta, 2016) impact the quality of sexual services. All the sex workers interviewed agree that commercial sex should be accessible to everyone (Browne; Russell, 2005; Jones, 2012), despite the presence or absence of any disability (Limoncin et al., 2014). Therefore, measures were suggested based on the experiences and obstacles professionals observed when working with people with disabilities. The most common and spontaneous solution mentioned was training. Sex workers also recognized the importance of training in order to provide adequate services and empower people with disabilities so they might make better decisions, which could benefit their sexual health. Limoncin et al. (2014) also believe in training to qualify professionals to attend clients with disabilities. The importance of legalizing sex work received widespread references, in accordance with the results found by Sanders (2007), in which many respondents reported they would resort to sex work if it were legal.

\section{Limitations and future perspectives}

The main limitation of this study lay on the participants, who are exclusively sex workers. Based on previous research with Portuguese people with disabilities, the focus of this investigation was sexual assistance, but in the absence of these professionals we interviewed sex workers in order to understand if the interest mentioned reflected a search for other sex services. The option to approach sex work professionals first instead of people with disabilities emerged from the fact that commercial sex services are a delicate subject, especially when provided to people with disabilities, and we aimed to explore the experiences between sex professionals and clients with disabilities to learn how training could improve sex services in Portugal.

Participants' narratives represent their interpretation of the experiences they lived and, for that reason, the results cannot be generalized to the experiences of every sex worker. Also, it is important to consider some level of subjectivity in the way the discourses were analyzed, since they depend on the researchers' point of view.

This investigation was an exploratory study, but further research on ethical questions, limitations and boundaries that might arise in this discussion is needed.

It is essential to study people with disabilities, more sex workers and even sexual assistants from other countries to reflect upon commercial sex services and how they can impact sexual health.

\section{Final considerations}

Sex worker experiences reveal how, for some Portuguese people with disabilities, commercial sex services are an option of sexual expression, which demystify the constructed idea of asexuality. Some sex workers have characteristics linked to sexual assistance in the literature. However, most professionals are not prepared to attend and assist this group nor respond to their sexual preferences and needs. Thus, considering health public policies in Portugal is an imperative. To answer the question of the title, the training of professionals to provide quality services, the creation of a legal framework and financial support might be important steps to improve the sexual health of clients.

Gender differences are another aspect for consideration in the purchase of sex, such as the double standard that men are praised for the same sexual behaviors women are criticized or pejoratively judged by (Crawford; Popp, 2003). This might explain the lack of female clients with disabilities. Therefore, raising awareness among professionals, families and society about the sexual rights of both men and women with any type of disability is essential. Sexual education would provide a good channel for empowering people with disabilities and the communities they live in. 
In conclusion, this study shows relevant findings to initiate a national debate about commercial sex services for people with disabilities and to think of training as a measure to improve sexual health. Commercial sex services might not be the solution for problems related to sexual expression experienced by people with disabilities, but it is a possibility that should be consciously considered.

\section{References}

ALVES, Z. M. B.; SILVA, M. H. D. Análise qualitativa de dados de entrevista: uma proposta. Paidéia, Ribeirão Preto, n. 2, p. 61-69, 1992.

BAHNER, J. Sexual professionalism: for whom? The case of sexual facilitation in swedish personal assistance services. Disability \& Society, Abingdon, v. 30, n. 5, p. 788-801, 2015.

BONI, V.; QUARESMA, S. J. Aprendendo a entrevistar: como fazer entrevistas em ciências sociais. Em Tese, Florianópolis, v. 2, n. 1, p. 68-8o, 2005.

BRAUN, V.; CLARKE, V. Using thematic analysis in psychology. Qualitative Research in Psychology, Abingdon, v. 3, n. 2, p. 77-101, 2006.

BRAUN, V.; CLARKE, V. Successful qualitative research: a practical guide for beginners. Londres: Sage, 2013.

BROWNE, J.; RUSSELL, S. My home, your workplace: people with physical disability negotiate their sexual health without crossing professional boundaries. Disability \& Society, Abingdon, v. 20, n. 4, p. 375-388, 2005.

CARDOSO, J. Sexualidade e deficiência. Coimbra: Quarteto, 2006.

CHRASTINA, J.; VECEROVÁ, H. Supporting sexuality in adults with intellectual disability a short review. Sexuality and Disability, Berlim, v. 38, p. 285-298, 2020.

CRAWFORD, M.; POPP, D. Sexual double standards: a review and methodological critique of two decades of research. Journal of Sex Research, Abingdon, v. 40, n. 1, p. 13-26, 2003. FONTANELLA, B. J. B. et al. Amostragem em pesquisas qualitativas: proposta de procedimentos para constatar saturação teórica. Cadernos de Saúde Pública, Rio de Janeiro, v. 27, n. 2, p. 389-394, 2011.

FRECKELTON, I. Sexual surrogate partner therapy: legal and ethical issues. Psychiatry, Psychology and Law, Abingdon, v. 20, n. 5, p. 643-659, 2013.

FRITSCH, K. et al. Disability and sex work: developing affinities through descriminalization. Disability \& Society, Abingdon, v. 31, n. 1, p. 84-99, 2016.

GAMMINO, G. R.; FACCIO, E.; CIPOLLETTA, S. Sexual assistance in Italy: an explorative study on the opinions of people with disabilities and wouldbe assistants. Sexuality and Disability, Nova York, v. 34, n. 2, p. 157-170, 2016.

GESSER, M.; NUERNBERG, A. H.; TONELI, M. J. F. A contribuição do modelo social da deficiência à psicologia social. Psicologia e Sociedade, Florianópolis, v. 24, n. 3, p. 557-566, 2012.

GEYMONAT, G. G. Disability rights meet sex workers' rights: the making of sexual assistance in Europe. Sexuality Research and Social Policy, Abingdon, v. 16, n. 2, p. 214-226, 2019.

GIRARD, M.; SASTRE, M. T. M.; MULLET, E. Mapping French people's views regarding sexual assistance to people with physical disabilities. Sexuality and Disability, Nova York, v. 37, n. 1, p. 1-13, 2018.

HUNT, X. et al. Dating persons with physical disabilities: the perceptions of South Africans without disabilities. Culture, Health and Sexuality, Abingdon, v. 20, n. 2, p. 141-155, 2017.

JONES, C. Paying for sex: the many obstacles in the way of men with learning disabilities using prostitutes. British Journal of Learning Disabilities, Hoboken, v. 41, n. 2, p. 121-127, 2012.

LAMBELET, A. Sexual assistance, suicide assistance and the condition of dependent older adults. In: LOFFEIER, I.; MAJERUS, B.; MOULAERT, T. Framing age: contested knowledge in science and politics. Nova York: Routledge, 2017. p. 95-110.

LANE, C. L. A.; CAMBRIDGE, P.; MURPHY, G. Muted voices: the unexplored sexuality of young 
persons with learning disability in Malta. British Journal of Learning Disabilities, Hoboken, v. 47, n. 3, p. 156-164, 2019.

LIDDIARD, K. I never felt like she was doing it for the money': disabled men's intimate (gendered) realities of purchasing sexual pleasure and intimacy. Sexualities, Thousand Oaks, v. 17, n. 7, p. $837-855,2014$.

LIMONCIN, E. et al. The psychosexual profile of sexual assistants: an internet-based explorative study. PLOS ONE, São Francisco, v. 9, n. 6, p. 1-6, 2014.

LOJA, E. Discriminação, indiferença e mobilização. In: MENEZES, I.; LOJA, E.; TEIXEIRA, P. M. (Orgs.).

(In) capacidade e (in)diferença: do indivíduo deficiente à sociedade incapacitante - justiça social, cidadania e autonomia das pessoas incapacitadas. Porto: CHE/Mais Leitura, 2014. p. 41-53.

MANNINO, G.; GIUNTA, S.; FIURA, G. L. Pyschodynamics of the sexual assistance for individuals with disability. Sexuality and Disability, Nova York, v. 35, n. 4, p. 495-506, 2017.

OLIVEIRA, M. P. A prostituição no sistema jurídico Português. 2017. Tese (Mestrado em Direito Forense e Arbitragem) - Faculdade de Direito da Universidade Nova de Lisboa, Lisboa, 2017.

OMS - ORGANIZAÇÃO MUNDIAL DA SAÚDE. Classificação Internacional de Funcionalidade, Incapacidade e Saúde. Lisboa, 2004.

PEREIRA, R.; TEIXEIRA, P. M.; NOBRE, P. J. Perspectives of Portuguese people with physical disabilities regarding their sexual health: a focus group study. Sexuality and Disability, Nova York, v. 36, n. 4, p. 389-406, 2018.

POELZL, L. Bisexual issues in sex therapy. Journal of Bisexuality, Abingdon, v. 1, n. 1, p. 121-142, 2000.

PORTUGAL. Lei ${ }^{0}$ 59/2007, de 4 de setembro de 2007. Diário da República, Lisboa, 4 set. 2007. Série I, p. 6190.

ROHLEDER, P. et al. Sexuality erased, questioned, and explored: the experiences of South Africans with physical disabilities. Psychology \& Sexuality, Abingdon, v. 9, n. 4, p. 1-11, 2018.
SANDERS, T. Female sex workers as health educators with men who buy sex: utilising narratives of rationalisation. Social Science and Medicine, Amsterdã, v. 62, n. 10, p. 2434-2444, 2006.

SANDERS, T. The politics of sexual citizenship: commercial sex and disability. Disability \& Society, Abingdon, v. 22, n. 5, p. 439-455, 2007. SANTOS, A. C.; SANTOS, A. L. Yes, we fuck! Challenging the misfit sexual body through disabled women's narratives. Sexualities, Thousand Oaks, v. 21, n. 3, p. 303-318, 2017.

SHAPIRO, L. Incorporating sexual surrogacy into the Ontario direct funding program. Disability Studies Quarterly, Columbus, v. 22, n. 4, p. 72-81, 2002.

UN - UNITED NATIONS. Convention on the rights of persons with disabilities. Nova York, 2007.

WAS - WORLD ASSOCIATION FOR SEXUAL HEALTH. Declaration on sexual pleasure. Cidade do México, 2019.

WHO - WORLD HEALTH ORGANIZATION. Sexual health, human rights and the law. Genebra, 2015.

WILLIAMS, D. J. et al. Introducing a multidisciplinary framework of positive sexuality. Journal of Positive Sexuality, [S.l.], v. 1, p. 6-11, 2015.

WOTTON, R. Sex workers who provide services to clients with disability in New South Wales. 2016. Tese (Mestrado em Filosofia) - University of Sydney, Sydney, 2016.

\section{Authors' contribution}

Pinho and Nogueira contributed to the conceptualization, design, and implementation of the research. Pinho conducted the data collection, analysis of the results and writing of the original draft with critical feedback from all authors. Nogueira and Oliveira supervised the development of the research. Pinho and Oliveira wrote the revision and edition of the manuscript.

Revised: 12/09/2019

Resubmitted: 03/05/2020

Approved: 04/22/2020 